\title{
自動車運転に影響を及ばす医薬品の処方に対する薬局薬剤師の対応
}

\author{
永田泰造, ${ }^{a}$ 山田純一, ${ }^{a}$ 大原 整, ${ }^{a}$ 木津純子 $*, b$
}

\section{Local Pharmacy Pharmacists' Responses to the Prescription of Drugs That Influence Driving}

\author{
Taizo Nagata, ${ }^{a}$ Junichi Yamada ${ }^{a}$ Hitoshi Oohara, ${ }^{a}$ and Junko Kizu ${ }^{*, b}$ \\ aJapan Pharmaceutical Association; 3-3-1 Yotsuya, Shinjuku-ku, Tokyo 160-8389, Japan: and ${ }^{b}$ Division of Practical \\ Pharmacy, Keio University Faculty of Pharmacy; 1-5-30 Shibakoen, Minato-ku, Tokyo 105-8512, Japan.
}

(Received September 9, 2016)

In 2013, the Ministry of Health, Labour, and Welfare issued a notification regarding drugs that influence driving. Afterward, a questionnaire survey of these drugs was conducted involving health insurance pharmacies in Tokyo and Shiga Prefectures. As a result, 503 (Tokyo) and 116 (Shiga) pharmacies provided completed questionnaires. The notification was sufficiently and slightly recognized by $20 \%$ and $44 \%$ of the surveyed pharmacies, respectively, and drugs with a driving-related warning were recognized by $31 \%$ of the pharmacies. In addition, $23 \%$ of the pharmacies reported that they always asked patients whether they drive. The influence on driving of antianxiety drugs, hypnotics, antiepileptics, and smoking-cessation drugs was always explained to patients by $74 \%, 72 \%, 64 \%$, and $40 \%$ of the pharmacies, respectively. Concerning responses to the prescription of drugs influencing driving, the proportion of surveyed pharmacies in Tokyo and Shiga Prefectures that directed patients not to drive was $71 \%$ and $53 \%$, respectively, and that directed patients to stop driving on developing any symptom was $32 \%$ and $49 \%$. Tokyo and Shiga Prefectures showed a significant difference in the reason for not prohibiting driving; the proportion of pharmacies that regarded strict medication adherence as of major importance to treat patients' primary diseases was $22 \%$ and $43 \%$, respectively. This difference might have been attributable to a high percentage of patients $(80 \%)$ driving to pharmacies in Shiga Prefecture. To facilitate the prescription of drugs influencing driving, it is recommended to design drug-specific pharmaceutical education manuals that also give consideration to patients' QOL.

Key words_ pharmacy; prescription medication; driving-related warning; package insert

\section{1. はじめに}

わが国は 70\%以上の人が自動車運転免許証を有

し，医療の高度化と高齢社会を迎えたことにより， なんらかの治療を受けながら自動車を運転している 人が少なからず存在する. ${ }^{1)}$ 道路交通法第 66 条で は，「何人も，過労，病気，薬物の影響その他の理 由により，正常な運転ができないおそれがある状態 で車両等を運転してはならない」と規定されてい る.しかし, 病気, 薬物の影響により事故に至って いるケースがある。一方，医薬品の副作用を恐れて 内服を中止し，様々な症状があるにもかかわらず，

${ }^{a}$ 日本薬剂師会 (干160-8389 東京都新宿区四谷 3-3-1), $b$ 慶應義塾大学薬学部（干105-8512 東京都港区芝公園 1-5-30)

*e-mail: kizu-jn@pha.keio.ac.jp

本総説は, 日本薬学会第 136 年会シンポジウムS64 で 発表した内容を中心に記述したものである.
我慢している患者もいる。しかし，医薬品を服用せ ず，未治療の状態では，疾病の悪化を招くため，医 薬品の使用は最優先されるべきである. ${ }^{2,3}$

2013 年 3 月 22 日, 総務省より厚生労働省に対し 「医薬品等の普及・安全に関する行政評価・監視結 果に基づく勧告」4)で，意識障害等の副作用報告が ある医薬品について，医療用医薬品添付文書（添付 文書）の使用上の注意における自動車運転等の禁止 等の記載を検討し，記載が必要なものについて速や かに各添付文書の改訂を指示するよう所見が示され た。さらに，同年 5 月 29 日，厚生労働省は都道府 県等に対して，「添付文書の使用上の注意に自動車 運転等の禁止等の記載がある医薬品を処方又は調剤 する際は，医師又は薬剂師から患者に対する注意喚 起の説明を徹底させること」と通知を出した，従 来，抗パーキンソン病薬（例 : プラミペキソール塩 酸塩水和物）は，前兆のない突発性睡眠や傾眠がみ 
られることがあり添付文書に警告として，「自動車 の運転等危険を伴う機械の操作には従事させないよ うに注意する」と記載されている。 また，抗真菌薬 のボリコナゾールは，羞明，霧視，視覚障害等の症 状が現れ，投与中止後も症状が持続することがあ り，投与中及び中止後もこれからの症状が回復する まで「自動車の運転等危険を伴う機械の操作には従 事させないように十分注意する」と同様に警告欄に 記載されている，また，眠気などにより，抗不安薬 (例：エチゾラム), 睡眠薬（例：トリアゾラム), 抗アレルギー薬（例：ケトチフェンフマル酸塩）, 抗てんかん薬（例：カルバマゼピン), 消炎鎮痛剤 (例：インドメタシン), 意識消失などにより疼痛治 療薬（例：プレガバリン), 抗うつ薬（例：フルボ キサミンマレイン酸塩), 禁煙補助薬（例：バレニ クリン酒石酸塩), 散瞳により散曈点眼薬（例：卜 ロピカミド・フェニレフリン)，視調節障害などに より鎮病薬（例：ブチルスコポラミン臭化物)，頻 尿治療薬（例：プロピベリン塩酸塩）, 緑内障治療 薬（例：ラタノプロスト), が添付文書の重要な基 本的注意に「自動車の運転等危険を伴う機械の操作 に従事させないように注意すること」と記載されて いる. さらに, 今回の通知に対応し, 添付文書に意 識障害等（意識レベルの低下，意識消失，意識変容 状態，失神，突発性睡眠）の記載のある医薬品につ いて見直しが実施され，認知症治療薬（例：ドネペ ジル塩酸塩）に自動車運転の禁止の記載, 抗菌薬 (例：レボフロキサシン水和物), 抗不整脈薬（例： ピルシカイニド塩酸塩水和物), 抗ウイルス薬(例 : アシクロビル), 糖尿病薬 (例：グリメピリド)に, 「自動車の運転等, 危険を伴う機械の操作に従事す る際には注意するよう患者に十分に説明すること」 との注意喚起が追記された.

しかしながら，これらの医薬品に関して具体的な 服薬指導指針等はなく, 該当医薬品が処方された際 の対応は，薬剂師に委ねられるため，薬剤師又は薬 局により対応が異なる可能性がある，そこで，薬局 薬剤師の通知に対する認知度や自動車運転を禁止す るように記載されている医薬品が処方された際に, どのような対応をとつているか把握することを目的 に調査を実施した。

\section{2. 調査方法}

2014 年 12 月 1 日-2015 年 1 月 15 日に東京都薬剤
師会に所属する薬局薬剤師に対し，各地域で実施さ れる研修会時にアンケートを実施した。さらに，同 期間に滋賀県薬剤師会に所属する薬局薬剤師 497 施 設を対象として FAX でアンケート用紙を送付して 調査を実施した。

アンケートは, 無記名選択方式 (一部複数選択可) で，最寄駅から薬局まで徒歩でかかる時間，薬局 （病院等への受診を含む）に自分で車を運転してく る患者の割合等の薬局に関する基本的情報とともに, (1)2013 年 5 月の厚生労働省からの通知についての 把握，(2)警告欄に自動車運転禁止の記載がある医薬 品についての把握, (3)該当医薬品が 18 歳以上に処 方されているとき, 自動車運転をするかについての 確認，(4)該当医薬品の服薬指導について，医薬品の 種類による説明内容の変更の有無，(5)自動車運転を している患者に，該当医薬品が処方されたときの対 応，6日常的に自動車運転をしている患者に該当医 薬品が処方されたときの対応で最も優先すべき事項, (7)患者に該当薬品が処方されていても，自動車運転 を禁止する服薬指導をしない場合の理由，8運転等 への影響について，患者にかならず注意喚起してい る医薬品等の項目について，調査を行った．回答は 東京都 503 薬局, 滋賀県 116 薬局 ${ }^{5)}$ から得られた.

\section{3. 薬局の最寄駅からの距離と自動車で薬局に来}

\section{る患者の割合}

東京都においては，最寄駅から薬局まで徒歩で 10 分以内の薬局が，482 薬局（本項目に関する無回

Table 1. Percentage of Patients Visiting the Pharmacy by Car According to the Time Required to Travel from a Nearby Station to the Pharmacy on Foot

\begin{tabular}{|c|c|c|c|c|}
\hline \multirow{2}{*}{ Area } & \multirow{2}{*}{$\begin{array}{c}\text { Time required } \\
\text { to travel from a } \\
\text { nearby station } \\
\text { to the pharmacy } \\
\text { on foot }\end{array}$} & \multicolumn{3}{|c|}{$\begin{array}{l}\text { Percentage of patients visiting } \\
\text { the pharmacy by car }\end{array}$} \\
\hline & & High & $\begin{array}{l}\text { Neither high } \\
\text { nor low }\end{array}$ & Low \\
\hline \multirow{3}{*}{$\begin{array}{l}\text { Tokyo } \\
(n=482)\end{array}$} & $\underset{(n=390)}{<10 \min }$ & $77(19.7 \%)$ & $54(13.8 \%)$ & $259(66.4 \%)$ \\
\hline & $\begin{array}{l}11-20 \min \\
(n=65)\end{array}$ & $21(32.3 \%)$ & $15(23.1 \%)$ & $29(44.6 \%)$ \\
\hline & $\underset{(n=27)}{>21 \min }$ & $18(66.7 \%)$ & $6(22.2 \%)$ & $3(11.1 \%)$ \\
\hline \multirow{3}{*}{$\begin{array}{c}\text { Shiga } \\
(n=111)\end{array}$} & $\begin{array}{l}<10 \min \\
(n=50)\end{array}$ & $37(74.0 \%)$ & $8(16.0 \%)$ & $5(10.0 \%)$ \\
\hline & $\begin{array}{c}11-20 \min \\
(n=31)\end{array}$ & $26(83.9 \%)$ & $3(9.7 \%)$ & $2(6.5 \%)$ \\
\hline & $\begin{array}{l}>21 \min \\
(n=30)\end{array}$ & $25(83.3 \%)$ & $4(13.3 \%)$ & $1(3.3 \%)$ \\
\hline
\end{tabular}


答の薬局を除外，以下同様）中 390 薬局と $80.9 \%$ を占め, 最寄駅から遠くなるにつれて自動車で来る 患者の割合が有意に増加していた $(p<0.01)$ ，滋賀 県では，徒歩で 10 分以内の薬局は，111 薬局中 50 薬局で $45.0 \%$ であり，最寄駅からの距離にかかわ らず自動車で来局する患者割合が $70 \%$ 以上であっ た (Table 1).

4. 厚生労働省の通知に対する薬剤師の把握状況 と添付文書に自動車運転禁止の警告記載がある医薬 品に対する認知度

厚生労働省の通知（自動車運転等の禁止等の記載 のある医薬品を調剂する際は，患者への注意喚起の 説明を徹底させる）について，「知っており内容も 十分把握していた」と回答した施設は，東京都が 93 施設 $(18.7 \%)$, 滋賀県が 29 施設 $(25 \%)$ ，「知 つており内容も少し把握していた」が 221 施設 (44.5\%) と 50 施設 $(43.1 \%)$ ，「知っていたが，内 容はほとんど把握していなかった」が 96 施設 (19.3\%）と 22 施設（19.0\%)，「知らなかった」は 87 施設（17.5\%）と 15 施設（12.9\%）であった。 通知後, 約 1 年半が経過しても，かならずしも十分 に浸透していないことが確認された。また，警告闌 の自動車運転禁止の記載については，「知つており 当該薬品も把握している」のは東京都が 153 施設 $(31.5 \%)$ ，滋賀県が 38 薬局 $(32.8 \%)$ ，「知ってい るが，どの医薬品かは不明」が 281 薬局 (57.8\%) と 65 薬局 $(56.0 \%)$ ，「知らない」は 52 薬局（10.7 \%) と 11 薬局 $(9.5 \%)$ であり，警告に記載がある 医薬品名を把握していない薬局が多いことが認めら れた。

5. 添付文書に自動車運転禁止等の記載がある医 薬品が処方された患者への自動車運転の確認・服薬 指導内容·対応

患者が自動車運転をしているかの確認 (複数回答) は，「かならず尋ねる」薬局は，東京都が 118 薬局 $(23.7 \%) ，$ 滋賀県 23 薬局 $(19.8 \%)$ であり，「患者 インタビュー用紙で確認」している薬局は，東京都 232 薬局 $(46.6 \%)$ ，滋賀県 58 薬局 $(50.0 \%)$ で あったが，「とくには尋ねない」と回答した薬局も 東京都 71 薬局 $(14.3 \%)$, 滋賀県 11 薬局 $(9.5 \%)$ であった (Table 2)。該当医薬品の服薬指導の内容 （複数回答）は，14.6\%の薬局は「一律にしている」 が，55.2\%の薬局は「医薬品の種類により変えてい
Table 2. Confirmation of Patients' Driving Status When Medications Affecting the Ability to Drive are Prescribed to Those Aged 18 Years or Older (Multiple answers were allowed)

\begin{tabular}{lcc}
\hline \hline & $\begin{array}{c}\text { Tokyo } \\
(n=498)\end{array}$ & $\begin{array}{c}\text { Shiga } \\
(n=116)\end{array}$ \\
\hline Always confirm & $118(23.7 \%)$ & $23(19.8 \%)$ \\
Confirm if the time permits & $107(21.5 \%)$ & $29(25.0 \%)$ \\
$\begin{array}{l}\text { Confirm using the record of } \\
\text { prescription medicine instruction }\end{array}$ & $145(29.1 \%)$ & $40(34.5 \%)$ \\
$\begin{array}{l}\text { Confirm using the items of the } \\
\text { patient interview form }\end{array}$ & $232(46.6 \%)$ & $58(50.0 \%)$ \\
Do not confirm & $71(14.3 \%)$ & $11(9.5 \%)$ \\
\hline
\end{tabular}

Table 3. Content of Instruction on Prescription Medications That Affect the Ability to Drive (Multiple answers were allowed)

\begin{tabular}{lcc}
\hline \hline & $\begin{array}{c}\text { Tokyo } \\
(n=463)\end{array}$ & $\begin{array}{c}\text { Shiga } \\
(n=113)\end{array}$ \\
\hline $\begin{array}{l}\text { The same instruction is provided to } \\
\text { all patients }\end{array}$ & $71(15.3 \%)$ & $13(11.5 \%)$ \\
$\begin{array}{l}\text { Content of instruction is changed } \\
\text { according to the types of medication }\end{array}$ & $251(54.2 \%)$ & $67(59.2 \%)$ \\
$\begin{array}{l}\text { Instruction is provided based on the } \\
\text { drug information sheet }\end{array}$ & $79(17.1 \%)$ & $20(17.7 \%)$ \\
$\begin{array}{l}\text { Content of instruction is changed } \\
\text { according to the level of effects of } \\
\text { medications on driving }\end{array}$ & $97(21.0 \%)$ & $20(17.7 \%)$ \\
\hline
\end{tabular}

Table 4. Responses When Driving-prohibited or -cautioned Medications Are Prescribed to Patients Who Drive on a Regular Basis (Multiple answers were allowed)

\begin{tabular}{lcc}
\hline \hline & $\begin{array}{c}\text { Tokyo } \\
(n=495)\end{array}$ & $\begin{array}{c}\text { Shiga } \\
(n=114)\end{array}$ \\
\hline $\begin{array}{l}\text { Ask for alternative medicines to a } \\
\text { prescribing physician }\end{array}$ & $29(5.9 \%)$ & $4(3.5 \%)$ \\
$\begin{array}{l}\text { Advise patients not to drive after } \\
\text { taking the medications }\end{array}$ & $356(71.9 \%)$ & $61(53.5 \%)$ \\
$\begin{array}{l}\text { Advise patients to stop the car } \\
\text { immediately if side effects occur }\end{array}$ & $160(32.3 \%)$ & $56(49.1 \%)$ \\
$\begin{array}{l}\text { Provide the drug information sheet } \\
\text { to let patients decide }\end{array}$ & $101(20.4 \%)$ & $27(23.7 \%)$ \\
No particular response & $15(3.0 \%)$ & $7(6.1 \%)$ \\
\hline
\end{tabular}

る」と回答した（Table 3)。自動車運転をしている 患者に，該当医薬品が処方されたときの対応（複数 回答）は，「処方医に該当医薬品の変更を提案する」 薬局は東京都 $5.9 \%$ ，滋賀県 $3.5 \%$ であったが，「服 用中は自動車運転をしないように服薬指導する」 （“禁止”とする）薬局は，東京都では 71.9\%，滋 賀県では $53.5 \%$ と差が認められた。ついで，「運転 中に症状が出たらすぐに車を止めるように服薬指導 
Table 5. The Most Important Points to Be Considered When Medications Affecting the Ability to Drive Are Prescribed to Patients Who Drive on a Regular Basis

\begin{tabular}{|c|c|c|c|c|c|c|}
\hline & \multicolumn{3}{|c|}{ Tokyo } & \multicolumn{3}{|c|}{ Shiga } \\
\hline & $\begin{array}{l}\text { Prohibition }{ }^{\mathrm{a}} \\
\quad(n=356)\end{array}$ & $\begin{array}{l}\text { Other than } \\
\text { prohibition }^{\text {b }} \\
\quad(n=139)\end{array}$ & $p$-value & $\begin{array}{l}\text { Prohibition }^{\mathrm{a}} \\
\quad(n=61)\end{array}$ & $\begin{array}{l}\text { Other than } \\
\text { prohibition }^{\mathrm{b}} \\
\quad(n=53)\end{array}$ & $p$-value \\
\hline $\begin{array}{l}\text { Avoid the danger caused by driving under the } \\
\text { influence of medication }\end{array}$ & $141(39.6 \%)$ & $32(23.0 \%)$ & $p<0.01$ & $25(41.0 \%)$ & $12(22.6 \%)$ & $p<0.05$ \\
\hline Explain the possible risks & $91(25.6 \%)$ & $57(41.0 \%)$ & $p<0.01$ & $28(45.9 \%)$ & $23(43.4 \%)$ & $p=0.788$ \\
\hline Patient's occupation & $32(9.0 \%)$ & $9(6.5 \%)$ & $p=0.110$ & $2(3.3 \%)$ & $6(11.3 \%)$ & $p=0.093$ \\
\hline Patient's daily life activities & $16(4.5 \%)$ & $5(3.6 \%)$ & $p=0.656$ & $1(1.6 \%)$ & $4(7.5 \%)$ & $p=0.125$ \\
\hline Modification of the prescription drugs & $10(2.8 \%)$ & $5(3.6 \%)$ & $p=0.646$ & $2(3.3 \%)$ & $0(0.0 \%)$ & $p=0.184$ \\
\hline Continue taking the medications to treat illness & $3(0.8 \%)$ & $5(3.6 \%)$ & $p<0.05$ & $4(6.6 \%)$ & $1(1.9 \%)$ & $p=0.225$ \\
\hline Content of prescription drug instructions & $18(5.1 \%)$ & $8(5.8 \%)$ & $p=0.754$ & $6(9.8 \%)$ & $6(11.3 \%)$ & $p=0.800$ \\
\hline Content of the drug information & $3(0.8 \%)$ & $1(0.7 \%)$ & $p=0.891$ & $0(0.0 \%)$ & $0(0.0 \%)$ & - \\
\hline Explanation given by the patient's physician & $22(6.2 \%)$ & $3(2.2 \%)$ & $p=0.066$ & $5(8.2 \%)$ & $5(9.4 \%)$ & $p=0.816$ \\
\hline
\end{tabular}

a Advise patients not to drive after taking the medications. ${ }^{\mathrm{b}}$ Advise patients to stop the car immediately if side effects occur, provide the drug information sheet to let patients decide and no particular response.

する」(“禁止以外”とする) 薬局も，東京都 32.3 \%，滋賀県 49.1\%であった（Table 4).これを薬局 に自動車で来る患者の割合が多いと回答した薬局 （204 薬局）と，患者の割合が少ないと回答した薬 局（299 薬局）で比較すると,「服用中は自動車運 転をしないように服薬指導する」は $59.0 \%$ と 72.3 \%,「運転中に症状が出たらすぐに車を止めるよう に服薬指導する」は $41.5 \%$ と $28.7 \%$ と差が認めら れた。

日常的に自動車運転をしている患者に該当医薬品 が処方されたときの対応で, 最も優先すべき事項に ついて, “禁止”を選択した薬局と“禁止以外”を 選択した薬局（上記の禁止以外に加え，「薬剤情報 提供文書を渡し患者の判断に任せる」と「特に何も していない」を加える）別に Table 5 に示した。 「服用後の自動車運転による危険を回避」を挙げた 薬局は, “禁止”を選択した薬局で有意に多かった （東京都 $p<0.01$, 滋賀県 $p<0.05$ ). “禁止以外”を 選択した薬局では，「起こり得る危険性の説明」が 最も多かった。また，“禁止以外”の回答をした薬 局を対象に，該当医薬品が処方されていても，自動 車運転を禁止する服薬指導をしない理由として, 「原疾患の治療には確実に服薬することが重要であ る」を挙げた薬局が東京都は $22.3 \%$ ，滋賀県では 43.4\%と差が認められた $(p<0.01)$. この差は, 東 京都では徒歩で薬局に来る患者が多いが, 滋賀県で は $80 \%$ の患者が自動車で来ることに関連している
Table 6. Major Reasons for Not Prohibiting Driving for Patients Being Prescribed Medications Affecting Their Ability to Drive (Pharmacies that selected "Other than prohibition")

\begin{tabular}{lcc}
\hline \hline & $\begin{array}{c}\text { Tokyo } \\
(n=139)\end{array}$ & $\begin{array}{c}\text { Shiga } \\
(n=53)\end{array}$ \\
\hline $\begin{array}{l}\text { It is important to take medications } \\
\begin{array}{l}\text { as prescribed in order to treat the } \\
\text { underlying disease }\end{array}\end{array}$ & $31(22.3 \%)$ & $23(43.4 \%)$ \\
$\begin{array}{l}\text { The prohibition of driving affects } \\
\text { patients' daily life and social activities }\end{array}$ & $25(18.0 \%)$ & $11(20.8 \%)$ \\
$\begin{array}{l}\text { Accidents caused by driving under the } \\
\text { influence of medication are quite rare }\end{array}$ & $3(2.2 \%)$ & $0(\quad 0 \%)$ \\
$\begin{array}{l}\text { Patients have no time to receive } \\
\text { advice on their medications }\end{array}$ & $1(0.7 \%)$ & $0(\quad 0 \%)$ \\
$\begin{array}{l}\text { The medications have been taken } \\
\text { for a while, but no side effects have } \\
\text { been reported }\end{array}$ & $11(7.9 \%)$ & $12(22.6 \%)$ \\
$\begin{array}{l}\text { Provide the drug information sheet } \\
\text { No response }\end{array}$ & $8(5.8 \%)$ & $4(7.5 \%)$ \\
\hline
\end{tabular}

と考えられる，ついで，「患者の日常・社会生活に 支障が出る」，「以前より服用し該当する副作用の発 現がないので問題ない」であった（Table 6).

\section{6. 服用後の自動車運転等への影響について患者} にかならず注意喚起している医薬品

「抗不安薬」,「睡眠薬」, 「抗てんかん薬」,「疼痛 治療薬」,「抗アレルギー薬」については, 東京都, 滋賀県のいずれにおいても，運転への影響について かならず注意喚起していると $50 \%$ 以上の薬局が回 答していた. しかし, 警告欄に自動車の運転を禁止 するよう記載がある「抗パーキンソン病薬」につい 


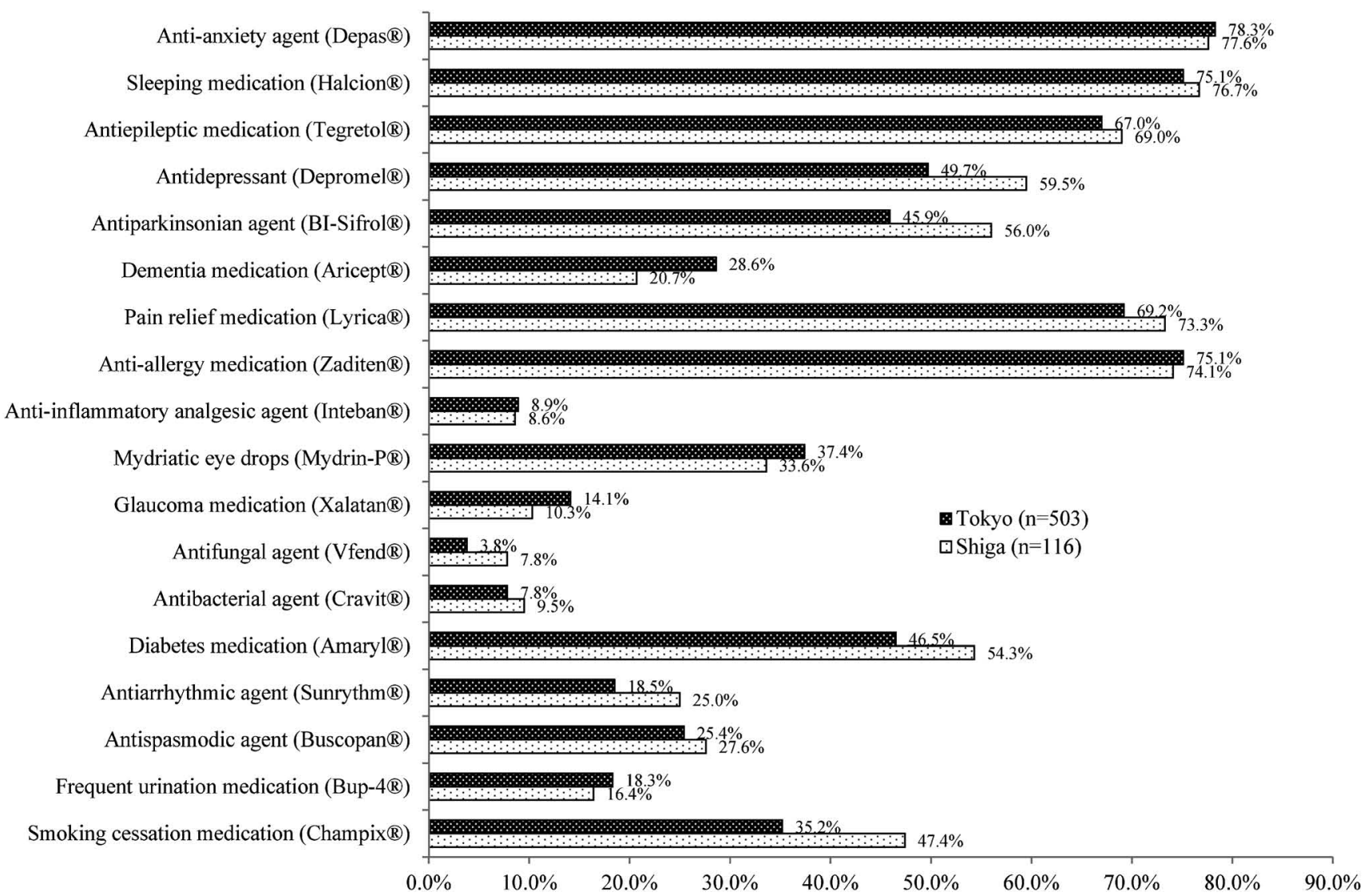

Fig. 1. Medications That Pharmacists Always Inform Patients of Their Risks of Driving (Multiple answers were allowed)

て，かならず注意喚起を行っている薬局は東京都 $45.9 \%$ ，滋賀県 $56.0 \%$ ，「抗真菌薬」は $3.8 \%$ と 7.8 \%であつた． 抗真菌薬のボリコナゾールの薬局にお ける処方頻度は高くないと考えられるが，ボリコナ ゾールの視覚に関する副作用の発現率は，国内第 III 相試験において $52 \%$ と高く，羞明，霧視，視覚障 害等の症状があらわれ，ボリコナゾール投与中止後 も症状が持続することがある，そのため，ボリコナ ゾール投与中及び投与中止後もこれらの症状が回復 するまでは，自動車の運転等危険を伴う機械の操作 には従事させないように十分注意すべきである。ま た，添付文書に服用時は自動車運転を禁止と記載さ れている「消炎鎮痛薬」，「散瞳点眼薬」，「緑内障治 療薬」,「鎮痙薬」,「頻尿治療薬」,「禁煙補助薬」も, かならず注意喚起している施設数が $50 \%$ 未満であ り，更なる注意喚起が必要であることが認められた (Fig. 1).

\section{7. まとめ}

今回の調査より，多くの薬剤師は，患者が日常的 に自動車を利用している場合，該当医薬品が処方さ
れたときの対応に苦慮していることが示された。患 者の自動車運転に関する精神科医のためのガイドラ インでは,「処方する医師としては, 薬物の開始時, 増量時などに，数日は運転を控え眠気等の様子をみ ながら運転を再開するよう指示する，その後も適宜 必要に応じて注意を促す，といった対応が現実的で あろう」という方針が示されている。 さらに，個々 の患者に最も適した処方や対処法を選択，指導する には，医師と薬剤師の連携体制も必要であると考え る．処方医に処方薬の変更を提案するとした施設は 33 施設だけであったが，薬剤師が患者へのインタ ビューや服薬指導の際に，患者の生活にとつて自動 車運転が必要との情報を得，代替品がある場合など は, 薬剤師から医師に処方薬の変更について提案す ることも，医薬品による自動車事故を避ける有用な 手段となり，処方医と薬剂師の連携は今後益々重要 なものになると考える.

本研究より，自動車運転を禁止することにより日 常・社会生活に支障が出る患者もおり，すべての患 者に一律に自動車運転を禁止する服薬指導をするの 
は困難であることが示唆された，治療を続けながら も自動車運転をせざるを得ない患者は多い。また, 医薬品によっては継続服用により眠気などの症状が 軽減されるものもある．服用開始時には車の運転を 避け，しばらく服用を続けたあとに，患者自身が効 果を確認するとともに，眠気や作業効率の低下の発 現について確認し，症状が認められないことが確認 できたら注意しながら運転を再開するよう指導する などの方法が妥当なケースもある. 今後, 該当医薬 品の処方に関して患者の QOL も考慮した具体的な 指導マニュアルの作成が望まれる.

謝辞本調査にご協力頂いた東京都薬剤師会会 員, 滋賀県薬剤師会会員の皆様に心より感謝申し上 げます。
利益相反 本稿で紹介した内容の一部は日本損 害保険協会自賠責運用益拠出事業の助成を得て行わ れた。

\section{REFERENCES}

1) Hitosugi M., Prog. Med., 32, 1595-1599 (2012).

2) Hitosugi M., Prog. Med., 32, 1643-1646 (2012).

3) Kizu J., Prog. Med., 32, 1647-1651 (2012).

4) Ministry of Internal Affairs and Communications. "Administrative evaluation and monitoring on the dissemination and safety of drugs.": 〈http://www.soumu.go.jp/menu news/s-news/000071649.html $\rangle$, cited 14 June, 2016.

5) Takahashi H., Matsumoto K., Kuroda Y., Oohara H., Kizu J., J. Jpn. Council Traffic Science, 15, 29-37 (2015). 